\title{
Offshore IT Outsourcing between India and New Zealand: A Systemic Analysis
}

\author{
Arun A Elias \\ Victoria Business School \\ Victoria University of Wellington \\ Wellington, New Zealand \\ Arun.Elias@vuw.ac.nz \\ Saji K Mathew \\ Department of Management Studies \\ Indian Institute of Technology Madras \\ Chennai, TN 600 036, INDIA \\ saii@iitm.ac.in
}

\begin{abstract}
This article aims to understand the complex interactions of factors related to IT offshore outsourcing between India and New Zealand. A systems approach was used to structure this problem situation and develop a model. This study undertook group model building exercises to construct a causal loop model that captured the underlying structure of the system. The analysis of the model revealed a set of eight feedback loops operating in the system identified as responsible for the complexity of the problem situation. In general, the literature on IT offshore outsourcing is based on clients' perspectives, while this study analyses the issue from a vendors' perspective. The paper concludes by highlighting a few strategies based on long term structural changes to improve IT offshore outsourcing between India and New Zealand.
\end{abstract}

Keywords: Offshore IT outsourcing, Systems thinking, Systems modelling 


\section{Introduction}

Global sourcing of IT has resulted in significant economic and strategic benefits to client firms and their IT service providers in different parts of the world (Lacity and Wilcocks, 1998; Carmel and Agarwal, 2002; Yuanyue et al., 2011). However some studies have also shown that trade in services and IT services in particular among different regions and countries of the world have shown distinctly different patterns (Carmel and Tjia, 2005; Schoenherr, 2010 ). In the Pacific-Asia region, both India and New Zealand have exhibited significant growth in their international trade in manufacturing and services. For example, India's import of services grew from US\$ 16,392 million during $2000-2001$ to US\$ 37,523 million during 2005-2006. In the same period, export of services grew from US\$ 18,870 million to US\$ 61,404 million (CECA, 2009). A similar growth trend is visible in New Zealand's services trade also, with import of services growing from US\$ 4,409 million in 2002 to US $\$ 8,281$ million in 2007 and that in exports growing from US\$ 4,777 million to US\$ 8,655 million during the same period (CECA, 2009). New-Zealand's developed economy has about $71 \%$ contribution from services. As a developing economy, India's services contributed about $69 \%$ of the overall average of its growth in the GDP during the five years from 20022003 to 2006-2007 (NASSCOM, 2009; Statistics New Zealand, 2011). The intent of both the nations to encourage and promote cross border trade is evident from the initiation of the New Zealand-India free trade negotiations during 2010-2011 (MFAT, 2013).

India has emerged as a main service provider nation in the field of offshore IT outsourcing. New Zealand, as a developed nation, recognising India's importance as an emerging power, has acknowledged the need for increasing its trade with India. Historically however, trade in IT between the two nations has been very low. New Zealand's import of computer and information services from India in the financial year ending in June 2012 was US\$ 7.21 million which accounts for just $1.31 \%$ of New Zealand's total import of the same service. For the fiscal year ending in March 2012, Indian IT industry's total export was estimated at US\$ 69 billion (Figure 1). Clearly, trade in IT services between the two countries is very low. In the past one and a half decades India's growing IT and IT enabled Services (ITeS) industry has received international recognition (Arora et al. 2001; Bhattacharya and Vickery, 2010), but it has also been characterised by an uneven profile with respect to its industry focus and geographic concentration (Heeks, 1998; CRISINFAC, 2009). A major part of the revenue flows has been from a few select industry sectors such as Banking, Financial Services and Insurance (BFSI), Telecom and Manufacturing (NASSCOM, 2009). In addition, the US contributes about $60 \%$ of the revenues followed by Europe $31 \%$ (CRISINFAC, 2009) and the remaining $9 \%$ from rest of the world. This surely exhibits a skewed distribution of client firms from the Indian IT industry perspective ${ }^{1}$. Our research enquiry is guided by a pertinent explanatory question in this context: why is the degree of trade in IT between New Zealand and India low?

\footnotetext{
${ }^{1}$ Note: India's IT industry provides services to a large number of Fortune 500 companies with a portfolio of service lines covering application development, system integration, infrastructure management and IT consulting. Offshore IT outsourcing contributes $66 \%$ of the industry's revenues.
} 


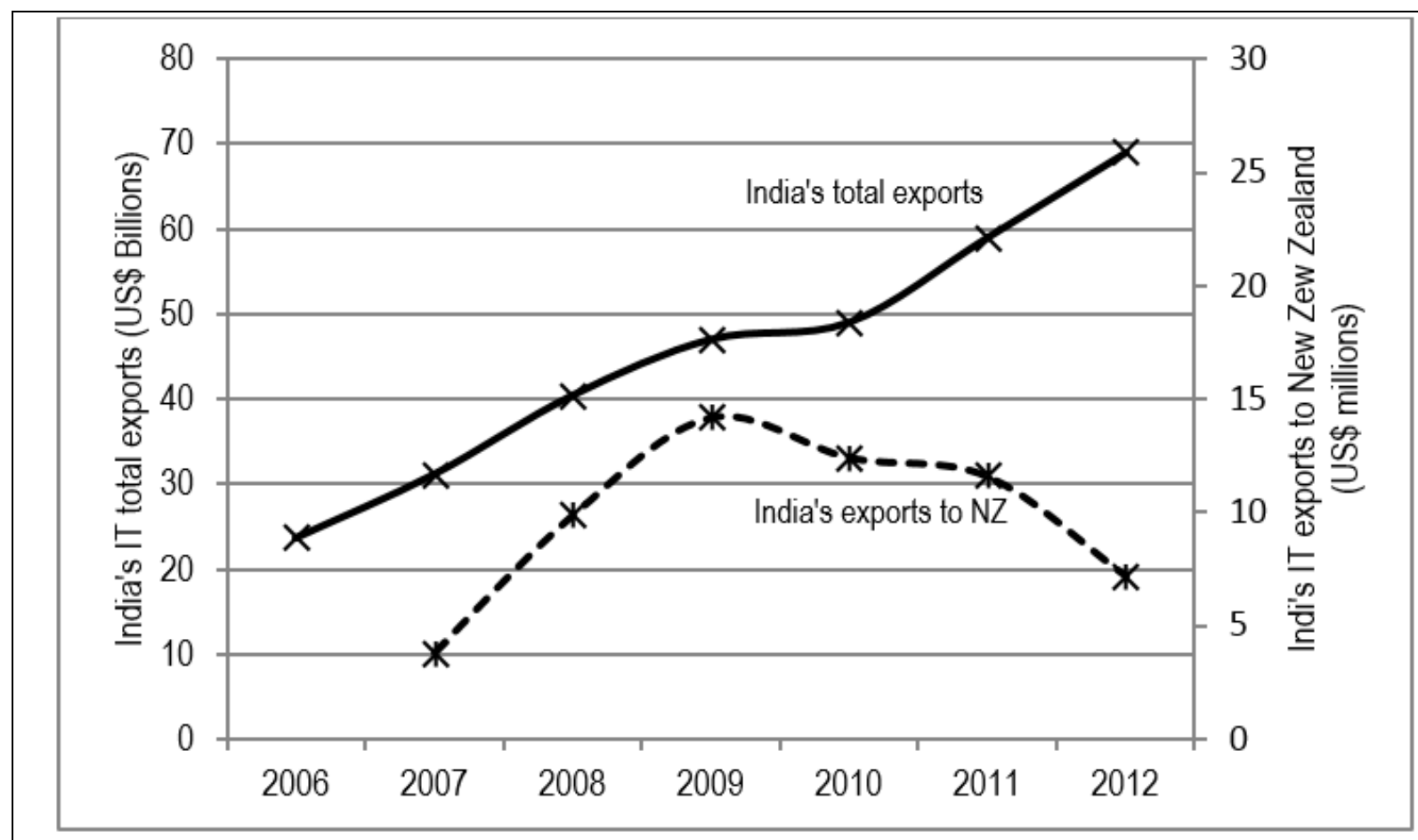

Figure 1 - India's IT export in the New Zealand context

Note: Data Sources: Statistics New Zealand \& NASSCOM

From a vendor's perspective, geographical concentration of IT exports is a source of risk as it increases the dependence of the industry on a few economies (CRISINFAC, 2009). Although several studies by government and industry bodies have reported concentration of trade in IT services between India and few developed countries only, studies examining the reasons for low engagements with other countries are few. A large body of literature in IT outsourcing addresses firm levels issues pertaining to clients (Aundhe and Mathew, 2009; Dibbern et al., 2004). A previous review of research literature in the area has reported major issues addressed by various scholars as outsourcing motivation, scope, performance, in-sourcing or outsourcing, contract and partnership (Lee et al.,2000; Yao et al., 2010). However, scholarly attention on outsourcing issues pertaining to service providers has been meagre, and systemic studies focussing on IT service provider's issues pertaining to geographical concentration hardly exist. In this context, this research seeks to understand the factors that affect the Indian IT vendors' choices of either selecting or not selecting clients based in New Zealand.

In summary, this study takes a vendor perspective of IT outsourcing and identifies geographical concentration as a major source of risk to vendor firms. Further, we investigate the specific context of Indo-New Zealand offshore IT outsourcing, observing that (a) both India and New Zealand are service based economies, and (b) while India's trade in IT with US and other developed European countries is substantial, it is relatively very low with New Zealand, which is also a developed country. The Indian IT industry is seeking to diversify its geographical portfolio (CRISINFAC, 2009), and in 2010 the New Zealand Government had also initiated talks with Indian Government to augment trade in services between the two nations (MFAT, 2013).

In this context, a systems model was developed to understand the complex inter- 
firm relationships in offshore IT outsourcing between India and New Zealand and it has been articulated as to how such a systems model can support IT vendors in the formulation of a service strategy. This study has developed a system model that explains the reasons for the low degree of outsourcing in IT between India and New Zealand, with particular focus on India based independent IT services vendors having international clients.

\section{Literature Review}

Cutting edge information technology, global markets and keen competition have forced companies around the world to change the way they manufacture and sell their products. Offshore outsourcing of information technology developed as a dominant sourcing model in IT due to the following reasons: decrease in transaction costs following economic liberalisation; drop in communication costs due to major advancements in information and communication technologies, labour arbitrage and availability of skilled IT labour force in offshore nations (Friedman, 2005; Carmel and Tjia, 2005). These conditions enabled firms to achieve cost efficiency, improve time to market, access global markets and attain the benefits of offshore outsourcing (Lacity and Willcocks, 1998; Manning et al., 2008). Among the manifold benefits of outsourcing IT services, cost efficiency has been identified as a major motivator (Lacity and Willcocks, 1998; Manning et al.,2008) and is seen as the strongest factor influencing the decisions of most ClOs looking to shift IT work offshore in the past decade (Escanlar, 2011).

Transaction Cost Economics (TCE) provides a theoretical foundation for firms to make a choice between the firm and the market in conducting an economic activity (Williamson, 1985), whereby firms can compare not only production costs but also the transaction costs in 'make or buy' decisions. According to this theory, there are three important aspects of a contract: behavioural, transactional and legal (Williamson, 1985, p. 43). TCE considers rationality and self-interest as two dimensions of behaviour. Whereas there could be different levels of these behavioural dimensions, bounded rationality and vendor opportunism are two manifestations which are sources of risk to a client. Further, TCE elicited three attributes of transactions that affect the type of governance structure chosen for an economic activity: i.) Asset specificity - as to which party has invested in assets pertaining to the transactions, ii.) Uncertainty - which is due to the bounded rationality and opportunism of the parties, and iii.) Frequency of transactions. When asset specificity and uncertainty are high, the risk of opportunism increases and therefore decision makers are likely to choose a firm based governance structure (in-sourcing). In the context of outsourcing this theory makes economic sense as to whether the market (vendor) or the firm (client) provides the lowest cost for IT activities (Aron et al., 2005). An early discussion on this topic and other reference theories analysing IT outsourcing from a client perspective are available in Lee et al.(2003). A recent study (Dou and Sarkis, 2010), drawing from the reference theories, provides an additional dimension of sustainability to further support client firms' selection of vendor partners and geographies in offshore outsourcing.

While some studies have analysed offshore IT outsourcing from the perspective of strategic management, a few early guidelines pertaining to 'outsource or not outsource' and process decisions on outsourcing were based on the theory of core competence, with a strong advise against outsourcing of core competence (Prahlad and Hamel, 1990). According to this school of thinking, firms considering outsourcing must identify core competence and peripherals activities of their business and then formulate an appropriate outsourcing strategy. However, some scholars, arguing that identifying core 
competence may not be tenable in all situations have suggested alternate frameworks for thinking (Clemons and Hitt, 1997). Further, certain conditions in the globalized world could also make outsourcing imperative for business sustainability despite the arguments to support opting out of outsourcing to protect core competence (Nohria, 2005). Global sourcing through partnership relationship with vendor firms have been successfully explored by several firms and client firms have shown maturity in global sourcing of formation technology (Lee and Kim, 2004; Linder, 2004; Gottfredson et al., 2005; Carmel and Tjia, 2005; Maskell et al., 2007).

Theories developed to aid client firms' strategic decisions do not provide much support for identifying and guiding strategic decisions of vendor firms. From a vendor's perspective, the early history of outsourcing and offshoring of IT appears to have been dependant more on the outsourcing firms' IT management strategy than on any service strategy formulated by the vendor firms. Loh and Venkatraman (1992) empirically analysed IT outsourcing contracts pertaining to the US and identified the perceived success of Eastman Kodak's IT outsourcing in 1989 (the Kodak effect) as a critical event (Gurbaxani, 1990) that triggered the early adoption of IT outsourcing by client firms. Carmel and Agarwal (2002) examined US firms outsourcing IT and reported different stages of maturity among them, ranging from firms that did not outsource at all through offshore experimenters and proactively cost focused firms to firms with a strategic focus on outsourcing. Similarly, Willcocks et al. (2007) described four levels of maturity in the outsourcing learning curve: firms that are dominated by hype and fear, early adopters who focus only on costs, more mature firms which focus on quality and firms which have institutionalized IT outsourcing to derive more value through transformational outsourcing. Although globalization, the subsequent maturation of IT outsourcing and its worldwide adoption led to economic and strategic benefits, several firms did not choose to adopt offshore outsourcing as a way of managing their IT (Carmel and Agarwal, 2002; Frenkel, 2002; Willcocks et al., 2006), due to a domestic mind set, inexperience in managing from a distance and inexperience in managing geographically dispersed projects. However, a systemic enquiry into the causes of low level of offshoring at a country level has been scarce. Barthelemy and Geyer (2005) empirically investigated the factors that influenced quasi outsourcing practices followed by firms in France and Germany and found that asset-specific IT activity, IT department size, IT internal organization, institutional environment, and IT-intensive sectors significantly impacted the outsourcing vs. quasi outsourcing decision by client firms. Recently, Schoenherr (2010) examined the outsourcing decision processes followed in 15 countries from a client perspective. However, there are no studies on the vendors' strategic decision process, and the current research is a pioneering effort in this area.

In summary, while previous research has predominantly focussed on theory building, testing and further extending theories to explain outsourcing from a client perspective, academic research on issues pertaining to vendor firms has been limited to certain specific topics like vendor risks (Aundhe and Mathew, 2009) and vendor value proposition (Levina and Ross, 2003; Khan et al., 2002). Specifically, studies addressing vendor strategy formulation, factors that influence the choice of geography, service line and industry sectors have not received due attention. Country selection, which is a very important issue in the context of offshore outsourcing, has been addressed from the client firms' perspective providing guidelines for country selection process and criteria that suits clients' desired objectives. Several scholars have suggested selection process and criteria that suits clients' desired objectives (Graf and Mudami, 2005; Palvia, 2004; Carmel and Tjia, 2005), but studies 
addressing vendors' country strategy are very few in extant literature. Although the geographic concentration of IT outsourcing in North America and Europe has been widely reported, a systemic enquiry into the causes for the low level of offshore outsourcing at a country level has been scarce. Though there are a few studies seeking to understand the determinants of quasi vs. full outsourcing in France and Germany, to the best of our knowledge, a study attempting to understand factors that influence the choice of offshore outsourcing in the New Zealand-India context is not found in literature.

\section{Methodological framework}

The methodology used in this study is based on systems thinking (e.g. Senge, 1990). According to management literature systems thinking approaches can be characterised as hard (e.g. Forrester, 1961), soft (e.g. Checkland, 1981), critical (e.g. Ulrich, 1987), and multi-methodology (e.g. Brocklesby, 1993). In the hard systems approaches, models are considered as abstractions of reality, while the soft systems approaches uses models for generating debate and insight about the real world. The soft systems methodology (Checkland, 1981) was developed out of the soft systems approach, when traditional systems thought was found to be an inappropriate set of tools for dealing with problems in which there was no clearly defined and commonly agreed set of outcomes. The critical systems approach tries to reveal the normative content of actual and proposed systems designs by critiquing the boundary judgements. According to the critical systems thinking, the practical implications of a proposition and thus its meaning as well as its validity depend on how the system of concern is bound. Multi-methodology involves combining different systems' methodologies from the hard, soft and critical approaches (Davies et al., 2005).This study took a hard systems approach using system dynamics (Sterman, 2000).

System dynamics was developed in the second half of the 1950s by Jay Forrester and his seminal book Industrial Dynamics continues to be a significant statement of philosophy and methodology in this field. System dynamics is a methodology for studying and managing complex systems involving multiple relationships, interdependencies and feedback, such as one finds in business and other social systems, through the development of representational models that can be used to reflect aspects of reality. System dynamics has been applied to issues ranging from corporate strategy to the dynamics of diabetes, from the cold war arms race between USSR and US, to the "combat" between HIV and the human immune system (Sterman, 2000). Existing literature on System dynamics acknowledges the complexity of the outsourcing decision and some attempts were made at analysing this complexity. McCray and Clarke Jr (1999) used system dynamics to anticipate the organisational impacts of outsourcing. Roehling et al. (2000) used system dynamics modelling to explore the dynamics of outsourcing relationships, including both positive and negative outcomes, as well as to provide potential support for strategic outsourcing decisions.

This study was limited to qualitative modelling based on systems dynamics (Cavana and Mares, 2004) using the systems thinking and modelling methodology (Maani and Cavana, 2007), which has been shown to be useful in analysing complex problem situations (e.g. Elias, 2008), and hence deemed appropriate. This methodology was also able to strike a delicate balance between hard and soft approaches to systems thinking. It starts with two qualitative phases, namely, problem structuring and causal loop modelling, which provides a solid foundation to develop a quantitative simulation model later, if required. This feature of the methodology provided more flexibility to this 
research, to develop a qualitative model and at the same time providing the scope to develop a simulation model later. While other systems methodologies like the soft systems methodology (Checkland, 1981) and the critical systems heuristics (Ulrich, 1987) can also be used to analyse complex problems situations, we used the systems thinking and modelling methodology since we were approaching this study from a positivistic research paradigm (Cavana et al., 2001).

The methodological framework used in this study consists of two phases. First, an attempt was made to structure the problem systemically. Second, a causal loop model was developed to capture the underlying feedback loops so as to explain the behaviour of the system. The first phase consisted of three steps, namely, collection of preliminary data and information, developing a chart for behaviour over time and collection of detailed information. The second phase also had a three step process which included development of the causal loop diagram, analysis of loop behaviour over time and development of intervention strategies.

We followed certain guidelines provided by Yin (2014, p. 45) to ensure validity and reliability of our case study research. We ensured construct validity by using multiple sources of evidence in our study. In order to understand behaviour over time we used data provided by Statistics New Zealand and NASSCOM and reports on trade relations between India and New Zealand provided by New Zealand Ministry of Foreign Affairs and Trade (MFAT) and Ministry of External Affairs (MEA), India. In addition to vendor representatives, the data sources for causal loop modelling also included interview respondents who were members of industry bodies like the NASSCOM who provided IT industry perspective. We also discussed and took feedback on the key findings of our study from experts in industry-academy forums in New Zealand. Internal validity was established by matching our findings with information available on Indo-US trade in IT services with market research findings of research bodies such as National Association of Software and Services Companies (NASSCOM) and CRIS INFAC. We developed causal loop models by choosing findings which were consistent across case sites in order to ensure external validity of our research.

Interviews were the primary method for collecting data. Twenty two interviews from fifteen firms were conducted with vendor executives, each lasting for about forty five minutes. A combination of structured and open ended questions was used during our interviews with vendor executives involving enquiries regarding the company's strategy on geography and service lines, factors that determine the choice of a country in strategy and the reasons for either having or not having clients in New Zealand. These questions triggered more elaborations on the company's experience with clients in New Zealand and other parts of the world. The interviews were conducted either face to face or on the telephone and extensive notes were taken, which were finally verified with the respondents.

\section{Data sources}

Table 1 exhibits the characteristics of the organisations and respondents chosen for conducting interviews. Table 2 provides a classification of the case sites based on size. 
Table 1 - Characteristics of respondents and their organisations

\begin{tabular}{|c|c|c|c|c|}
\hline $\begin{array}{l}\text { SI } \\
\text { no }\end{array}$ & Firm and its business & $\begin{array}{l}\text { Clients in } \\
\text { New } \\
\text { Zealand }\end{array}$ & $\begin{array}{l}\text { Geographical } \\
\text { focus }\end{array}$ & $\begin{array}{l}\text { Respondents/ } \\
\text { Interview No. }\end{array}$ \\
\hline 1 & Small Indian IT services company & No & USA & CEO (1) \\
\hline 2 & $\begin{array}{l}\text { Small Indian IT company, specializing } \\
\text { in R\&D }\end{array}$ & No & USA & CEO (2) \\
\hline 3 & $\begin{array}{l}\text { Medium sized French IT services firm } \\
\text { with major presence in India }\end{array}$ & No & Europe & $\begin{array}{ll}\text { Principal } & \text { Delivery } \\
\text { Manager (3) } & \\
\end{array}$ \\
\hline 4 & $\begin{array}{l}\text { Large French IT services firm with } \\
\text { major presence in India }\end{array}$ & No & Europe, USA & Director (4) \\
\hline 5 & $\begin{array}{l}\text { Large US IT services firm with major } \\
\text { presence in India }\end{array}$ & Yes & USA/UK & $\begin{array}{l}\text { Chief-Corporate } \\
\text { Affairs (5), Senior VP } \\
\text { (6) }\end{array}$ \\
\hline 6 & $\begin{array}{l}\text { Medium sized Indian IT } \text { services } \\
\text { provider specializing in financial } \\
\text { services sector }\end{array}$ & Yes & $\begin{array}{l}\text { USA, Europe, } \\
\text { Asia-Pacific }\end{array}$ & $\begin{array}{l}\text { Partner Head (7), } \\
\text { Head -Australia, New } \\
\text { Zealand (8) }\end{array}$ \\
\hline 7 & $\begin{array}{l}\text { Large Indian IT services firm with } \\
\text { office in New Zealand }\end{array}$ & Yes & USA, Europe & $\begin{array}{l}\text { VP (9), Associate VP } \\
(10)\end{array}$ \\
\hline 8 & $\begin{array}{l}\text { Medium sized Indian IT services firm } \\
\text { specializing in travel, tourism and } \\
\text { logistics sector }\end{array}$ & Yes & $\begin{array}{l}\text { USA, Europe, } \\
\text { Asia-pacific }\end{array}$ & $\begin{array}{l}\text { Senior Manager (11), } \\
\text { VP-Commercial } \\
\text { operations (12), } \\
\text { Head -Service } \\
\text { Delivery (13) }\end{array}$ \\
\hline 9 & Large Indian IT services firm & Yes & USA, Europe & $\begin{array}{l}\text { Quality assurance } \\
\text { executive in New } \\
\text { Zealand (14), } \\
\text { Manager (15) }\end{array}$ \\
\hline 10 & $\begin{array}{l}\text { Internal IT department of a large bank } \\
\text { in New Zealand }\end{array}$ & Yes & - & $\begin{array}{l}\text { Manager/Consultant } \\
(16)\end{array}$ \\
\hline 11 & $\begin{array}{l}\text { Small IT Vendor specializing in Billing } \\
\text { software }\end{array}$ & Yes & $\begin{array}{l}\text { Asia-pacific, } \\
\text { Europe, USA }\end{array}$ & $\begin{array}{l}\text { Head-Consulting (17), } \\
\text { GM-Corporate } \\
\text { Resources (18) }\end{array}$ \\
\hline 12 & Large Indian IT services firm & Yes & USA, Europe & Head-BPO (19) \\
\hline 13 & Large Indian IT services firm & Yes & $\begin{array}{l}\text { USA, Europe } \\
\text { Asia pacific }\end{array}$ & Manager (20) \\
\hline 14 & Large Indian IT services firm & Yes & $\begin{array}{l}\text { USA, Europe, } \\
\text { Middle east and } \\
\text { Asia pacific }\end{array}$ & Head (Delivery) (21) \\
\hline 15 & Large Indian IT services firm & Yes & $\begin{array}{l}\text { USA, Europe, } \\
\text { Middle east and } \\
\text { Asia pacific }\end{array}$ & $\begin{array}{l}\text { Senior Technical } \\
\text { Associate (22) }\end{array}$ \\
\hline
\end{tabular}

The following criteria were adhered to while selecting the sites: (i) The organisation should have been in IT outsourcing relations with a foreign partner for at least 5 years; (ii) The organisation should have clients in New
Zealand/Australia or is actively considering New Zealand as a country to do business in (iii) The organisation was willing to give us access to one or more key informants in their senior management. 


\begin{tabular}{|l|c|c|}
\hline Table 2 - Case sites by size & Number of NZ Clients \\
\hline Type of Case Site & Number of Sites & 1 \\
\hline Small & 3 & 2 \\
\hline Medium & 3 & 8 \\
\hline Large & 9 & \\
\hline
\end{tabular}

Key informant validity was also ensured for those who responded to our questions on behalf of their organisations. Following the guidelines provided by Kumar, Stern and Anderson (1993), the respondents selected for interviews had (i) adequate experience in IT outsourcing engagements, and (ii) were actively involved in the strategic decision making process of offshore outsourcing (Table 1). In our sample of 15 IT companies, 14 were either Indian born companies or companies head quartered abroad but having a major presence in India. In addition, we also interviewed an executive of the Internal IT department of a major New Zealand bank. The sample was a good mix of large (9), medium (3) and small sized companies (3). Further, 11 out of the 13 firms had clients in New Zealand, and the other 4 firms were exploring New Zealand as a prospective location in the near future.

\section{Problem structuring}

To gain a systemic understanding of the problem situation, a problem structuring exercise was conducted in the first phase of this study involving three steps, namely, collection of preliminary information and data, developing behaviour over time chart and collection of detailed information.

To gain a broader understanding of the problem, data about New Zealand's IT imports for years 2006 to 2012 was collected from the web site of Statistics New Zealand (Table 3). All the financial figures given in NZ\$ were converted to US\$ by using exchange rates of the corresponding years. India's IT export data was collected from the website of NASSCOM, an industry body for the promotion of Indian IT industry.

\begin{tabular}{|c|c|c|c|c|c|c|c|}
\multicolumn{6}{|c|}{ Table 3 - India's contribution to New Zealand's IT } \\
\hline Year & 2006 & 2007 & 2008 & 2009 & 2010 & 2011 & 2012 \\
\hline $\begin{array}{c}\text { NZ total IT } \\
\text { imports (USD) }\end{array}$ & 244.81 & 323.84 & 384.18 & 371.32 & 364.98 & 517.67 & 549.79 \\
\hline $\begin{array}{c}\% \text { IT imports } \\
\text { from India }\end{array}$ & confidential & $1 \%$ & $3 \%$ & $4 \%$ & $3 \%$ & $2 \%$ & $1.31 \%$ \\
\hline
\end{tabular}

Note: Data source: Statistics New Zealand, http://www.stats.govt.nz/

To structure the problem further a 'Behaviour over Time (BOT)'graph was developed. BOT graph or 'reference mode behaviour' is a tool used in systems thinking to show the patterns of the main variables in a system over an extended period of time, typically several months to several years. This pattern can indicate the variations and trends in the variable of interest, for example growth, decline, oscillations or a combination thereof. The important elements of a BOT are the overall directions and variations, not the numerical value of the variable. Therefore, BOT graphs are usually drawn in a rough sense without 
exact numerical values attached (Maani and Cavana, 2007).

For this study, a BOT graph was drawn using the trends of following three variables: total IT exports from India, total IT imports to New Zealand, and IT exports from India to New Zealand. Figure 2 presents this behaviour, showing an increasing trend of IT exports from India. It also shows that IT imports to New Zealand is increasing, however, it shows that IT exports from India to New Zealand is not showing a corresponding increase and have not really picked up momentum.

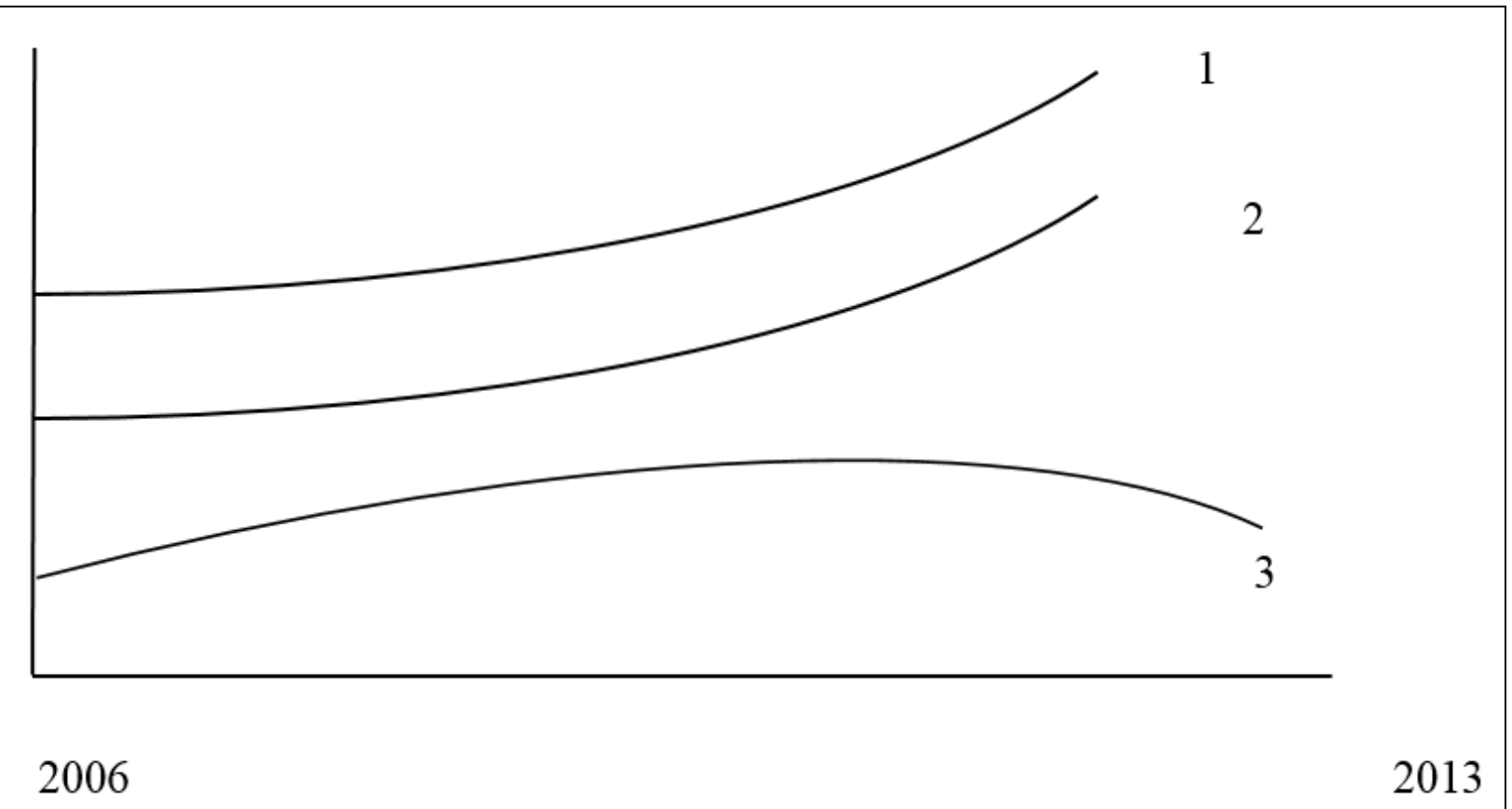

\section{Figure 2 - Behaviour Over Time}

Note: $1=$ Total IT exports from India, 2= Total IT imports to New Zealand, $3=$ IT exports from India to New Zealand.

Face to face or telephonic interviews were conducted for collecting detailed information. Following the guidelines provided by Sterman (2000) the interview data was analysed to identify variables in the system. An inductive approach was predominantly followed in data collection and analysis (Strauss and Corbin, 1990). During the course of the interviews different concepts on vendor's perspective on country selection and 'why or why not New Zealand' questions were re-framed to draw more insights on the concepts. The texts of the interview summaries were analysed to identify factors that played a role in country selection as highlighted by the respondents. Variables (concepts) were labelled on the basis of the semantics of items drawn from the data. 


\begin{tabular}{|c|c|c|}
\hline Category/Loop & Variable Name & Variable Definitions \\
\hline US Influence & $\begin{array}{l}\text { US firms interested in IT offshore } \\
\text { outsourcing to India } \\
\text { US client initiated vendors in India } \\
\text { US connection and history in Indian IT } \\
\text { offshore outsourcing } \\
\text { Indian IT exports to US } \\
\text { Expertise in serving US clients } \\
\text { Quality of service to US clients } \\
\text { Perception of job losses in US } \\
\text { US political pressure against IT offshore } \\
\text { outsourcing to India } \\
\text { Indian vendors' interest in other } \\
\text { geographies }\end{array}$ & $\begin{array}{l}\text { Number of US firms interested in IT } \\
\text { offshore outsourcing to India } \\
\text { Number of US client initiated vendors in } \\
\text { India } \\
\text { Number of US connections and its rich } \\
\text { history in Indian IT offshore outsourcing } \\
\text { Value of Indian IT exports to US in US\$ } \\
\text { Level of expertise in serving US clients } \\
\text { Level of service quality in serving US } \\
\text { clients } \\
\text { Level of fear about job losses in US } \\
\text { Strength of US political pressure against } \\
\text { IT offshore outsourcing to India } \\
\text { Strength of Indian vendors' interest in } \\
\text { exploring other geographies }\end{array}$ \\
\hline $\begin{array}{l}\text { New Zealand } \\
\text { Opportunities }\end{array}$ & $\begin{array}{l}\text { Chances of New Zealand as an option } \\
\text { Opportunity analysis of New Zealand as } \\
\text { a location } \\
\text { Attractiveness of language compatibility } \\
\text { Attractiveness of skill shortage } \\
\text { Attractiveness of technological } \\
\text { advancement } \\
\text { Location attractiveness of New Zealand }\end{array}$ & $\begin{array}{l}\text { Probability of New Zealand as an } \\
\text { outsourcing option for Indian vendors } \\
\text { Level of opportunity analysis of New } \\
\text { Zealand as a location by Indian vendors } \\
\text { Attractiveness of New Zealand due to its } \\
\text { language compatibility for Indian } \\
\text { vendors } \\
\text { Attractiveness of New Zealand due to its } \\
\text { skill shortage for Indian vendors } \\
\text { Attractiveness of New Zealand due to its } \\
\text { technological advancement for Indian } \\
\text { vendors } \\
\text { Overall attractiveness of New Zealand } \\
\text { as a location for Indian vendors }\end{array}$ \\
\hline $\begin{array}{l}\text { Inherent } \\
\text { Weaknesses of } \\
\text { New Zealand }\end{array}$ & $\begin{array}{l}\text { Risk analysis of New Zealand as a } \\
\text { location } \\
\text { Perception of size as a risk } \\
\text { Perception of distance as a risk } \\
\text { Perception of connectivity as a risk } \\
\text { Interest of Indian companies in other } \\
\text { geographical locations }\end{array}$ & $\begin{array}{l}\text { Level of risk analysis of New Zealand as } \\
\text { a location by Indian vendors } \\
\text { Perception of size of market as a risk for } \\
\text { Indian vendors } \\
\text { Perception of distance between New } \\
\text { Zealand from India as a risk for Indian } \\
\text { vendors } \\
\text { Perception of connectivity between India } \\
\text { and New Zealand as a risk for Indian } \\
\text { vendors } \\
\text { Level of interest of Indian companies in } \\
\text { exploring other geographical locations }\end{array}$ \\
\hline $\begin{array}{l}\text { Attitude of New } \\
\text { Zealanders }\end{array}$ & $\begin{array}{l}\text { Number of Indian vendors in New } \\
\text { Zealand } \\
\text { Cultural issues }\end{array}$ & $\begin{array}{l}\text { Number of Indian vendors who went to } \\
\text { New Zealand } \\
\text { Issues between Indian vendors and } \\
\text { New Zealand clients due to cultural } \\
\text { reasons } \\
\text { Number of success stories of Indian } \\
\text { vendors }\end{array}$ \\
\hline Service Quality & $\begin{array}{l}\text { Deployment of quality resources by } \\
\text { Indian vendors } \\
\text { Quality of service to New Zealand } \\
\text { clients }\end{array}$ & $\begin{array}{l}\text { Quality of IT professionals deployed by } \\
\text { Indian vendors } \\
\text { Level of service quality in serving New } \\
\text { Zealand clients }\end{array}$ \\
\hline
\end{tabular}




\section{Causal loop modelling}

Based on the guidelines provided by Sterman (2000), the variables extracted from the interview data were used to develop a causal loop model to capture the underlying structure of the problem. Most of the cause and effect relationships were directly supported by the interview data. Additional causal links were also used to supplement the interview data, using our own experiences, observations and archival data (Sterman, 2000) in order to explain the behaviour captured in the BOT graph. Each causal link was assigned a polarity, either positive $(+)$ or negative $(-)$, to indicate how the dependent variable changes when the independent variable changes (Sterman, 2000).

Once a group of variables was linked together in a connected path, a feedback loop was formed. Every feedback loop tells a story, which shows how the effects eventually catch up with the cause, or how the end meets the means (Maani and Cavana, 2007). The feedback loops derived in this model have been used to explain the behaviour of the system captured in the BOT graph.
Management literature has acknowledged the importance of capturing the interdependent linkages arising from common systemic factors (Dungey et al., 2003), and causal loop models are developed using these linkages. Causal loop models can also be considered as visual representations of cause-effect relationships among elements of a system forming structures of feedback loops (Mohapatra et al., 1994). The causal loop model developed in this study is presented in Figure 3.

An analysis of the casual loop model was done by identifying the different feedback loops formed in the model. Systems thinking literature classifies feedback loops as either reinforcing or balancing. Reinforcing loops are positive feedback systems while balancing feedback loops are negative feedback systems. Reinforcing loops represent growing or declining actions and balancing loops seek stability or return to control (Sterman, 2000).

Eight feedback loops were identified in the model. Of this, five were reinforcing while the remaining were balancing loops. The analysis of these eight feedback loops are discussed below.

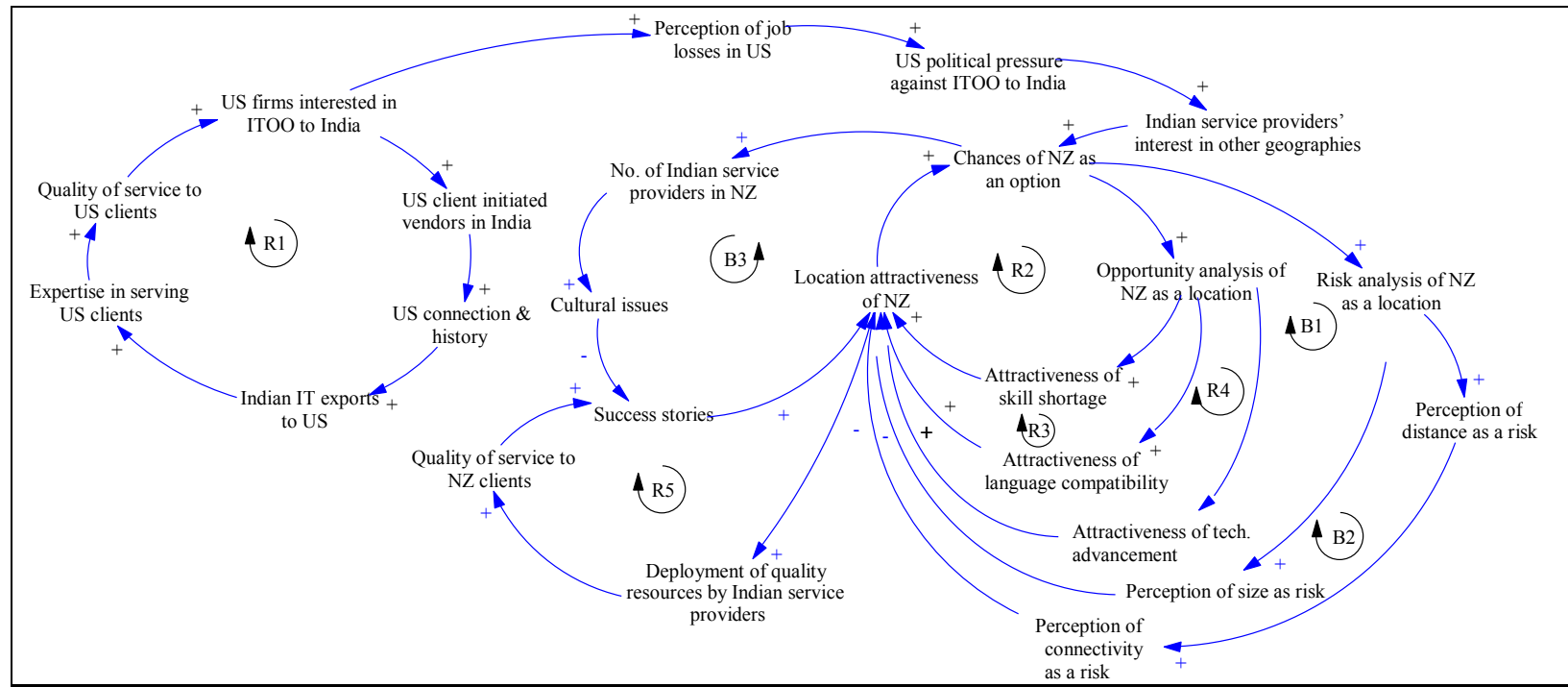

Figure 3 - Causal Loop Model

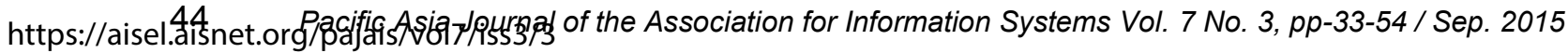




\section{Loop 1: India - US history loop (R1)}

A possible starting point to this causal loop analysis is the variable of the US firms interested in IT offshore outsourcing (ITOO) to India. As per the 'India -US history loop', when the number of US firms interested in IT offshore outsourcing increases, the number of Indian vendors initiated by these US clients would also increase. Those vendors in turn will bring in more US connections and their history will be connected to their US clients, leading to increased Indian IT exports to US. When Indian IT exports to US increase, expertise in serving US clients and in turn the quality of service, including cost savings to US clients improves. Such quality of services results in an increasing number of US firms interested in IT offshore outsourcing to India, thus completing a reinforcing feedback loop (Figure 4).

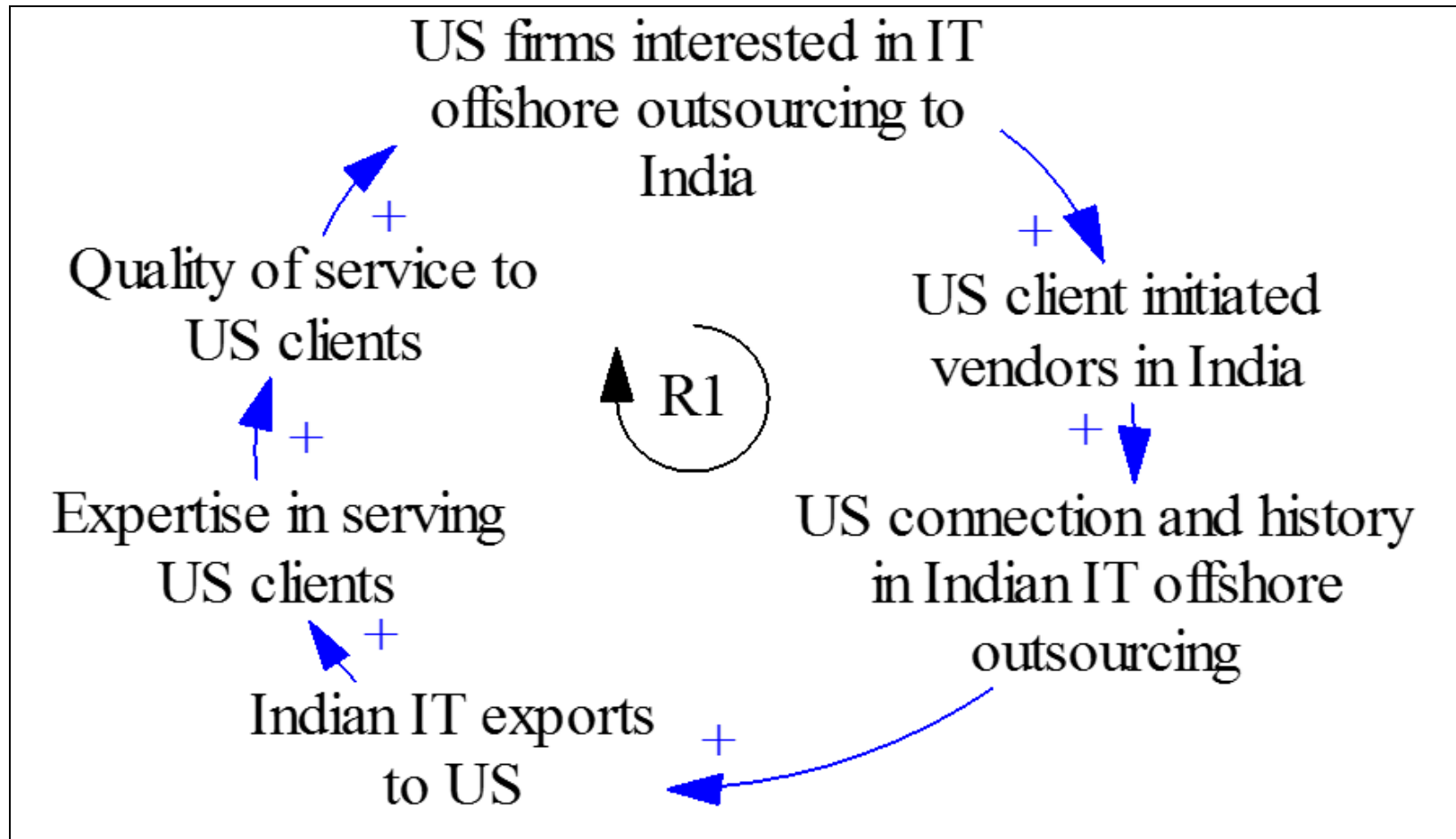

\section{Figure 4 - US History loop}

Our interviews revealed that most of the Indian vendors had historical links with one or more US companies. As an example, the Senior Vice President of a large IT service firm mentioned:

"Actually we are originally an American multinational corporation and we provide custom information technology, consulting, and business process outsourcing services. But around two thirds of our employees are based in India. Our US connections are so strong and we are experts in serving the US market."
A recent academic study has shown how education received from North America has influenced top researchers throughout Asia (French and Shim, 2013). This further corroborates our finding.

\section{Loop 2: Skill Shortage Opportunity loop}

The second, third and fourth loops explain the opportunities for NZ as an IT offshore location. When IT exports from India to US increase beyond a level, the perception of job losses within US increases. Such perceptions about job losses will encourage 
some US politicians to fight against IT offshore outsourcing to India. This situation will force Indian vendors to look for destinations other than the US and New Zealand's chances as one such destination increases. At this point, most professional vendors would conduct an opportunity and risk analysis for the different alternative locations available to them, as explained by a senior technical associate in a large Indian IT service firm:

"We started looking at many countries when we realised that US market is going to be difficult in the future. We had a team of people who looked at various risks as well as opportunities in the Asia Pacific region. They did consider Australia and New Zealand as potential options."

Such an opportunity analysis will highlight the attractiveness of New Zealand, a country with acute skill shortage, thereby improving the chances of New Zealand as an option for Indian vendors to engage in IT offshore outsourcing. Technically this loop
(R2) is a reinforcing feedback loop (Figure $5)$.

\section{Loop 3: Language Compatibility Opportunity loop}

The third loop is similar to the second loop. An opportunity analysis will also highlight the fact that India and New Zealand have English as the common language between them. This will increase the attractiveness of New Zealand as a location with a compatible language, thus encouraging Indian vendors to engage in IT offshore outsourcing with New Zealand. Technically, this is another reinforcing feedback loop (R3).

The CEO of a small Indian IT services company said:

"We realise that compared to Europe, New Zealand and Australia are easier territories. We are part of the common wealth, with English as a common language and cricket as a common sport."

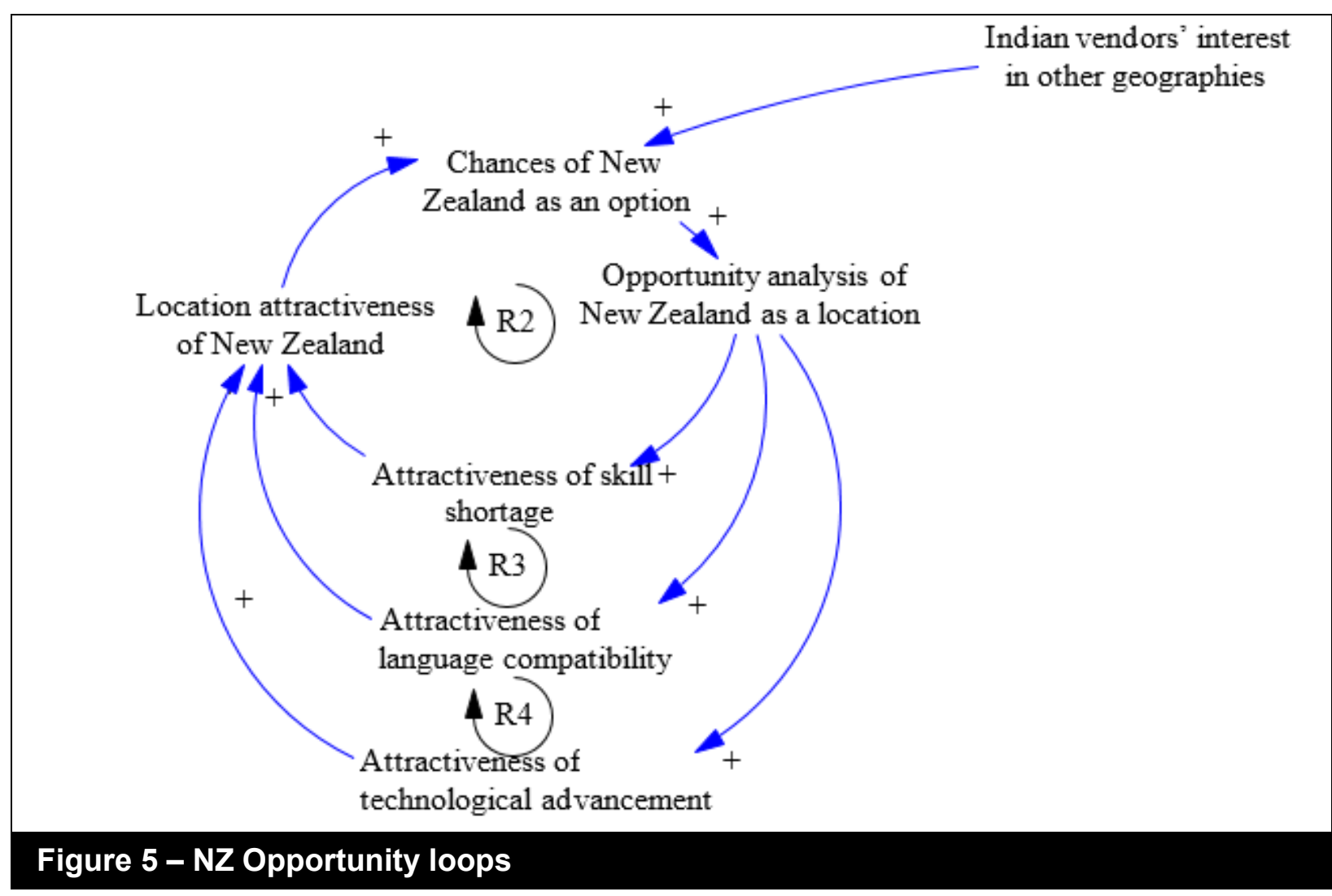

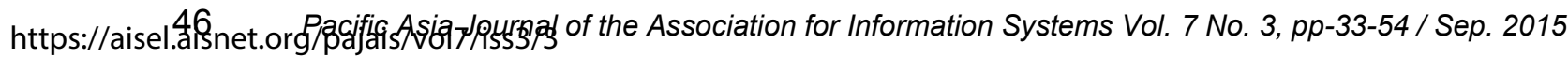




\section{Loop 4: Technology Advancement Opportunity loop}

The fourth loop is similar to the second and third loop. An opportunity analysis will project New Zealand as a technologically advanced nation with a high potential for outsourcing. This will increase the attractiveness of New Zealand as a location and will encourage Indian vendors to engage in IT offshore outsourcing with New Zealand. This is yet another reinforcing feedback loop (R4).

The Vice President of an India based Software Company recalled:

"No major difference between western clients and New Zealand clients in my experience [sic]. New Zealand is technologically advanced and even more process oriented in work than their Western counter parts."

\section{Loops 5 and 6: Risk Analysis loops (B1 and B2)}

As explained in the previous section, when Indian vendors consider New Zealand as a destination for IT offshore outsourcing, they will conduct both opportunity and risk analyses. The loops associated with opportunity analysis were explained using loops R2 and R3 while the effect of risk analysis is explained using loops B1 and B2. A risk analysis of New Zealand as a location will highlight the perception of its small size as a risk. It will also show distance and connectivity as risks. Such perceptions will reduce the attractiveness of New Zealand as a location for Indian vendors, thereby affecting India's IT exports to New Zealand negatively. This situation will reduce the chances of New Zealand as an option, thus completing the two balancing loops B1 and B2 (Figure 3).

The Senior Manager of a medium sized Indian IT services firm specializing in travel, tourism and logistics sector observed during the interview regarding US that influence, attitudinal and inherent weaknesses of New
Zealand reduced its attractiveness as a location:

We went to bigger markets like USA or Australia and did it try to expand its own its presence in NZ. We focused on bigger places, as NZ only has 3 million people. $N Z$ market is smaller and is far away. Also $N Z$ was a "closed" country that time; import was very difficult Government permission was needed for imports. Only after 1990s NZ economy "opened up" like India. To import anything to the country reserve bank permission was needed."

The country Director of a large French IT services firm with major presence in India commented on the company's opportunity assessment of New Zealand market and reasons for opting out of the country as follows:

"Another consideration during our evaluation is the ability to reach out to other potential markets/countries in the vicinity from that location, say going to South Africa and then expanding to other African countries. Since New Zealand and Australia are the only countries in that region with limited market size, they do not provide potential access to a cluster of countries as in Europe."

\section{Loop 7: New Zealander Attitude loop (B3)}

This loop explains the experience of some Indian vendors who went to New Zealand. As per this loop, when the chances of New Zealand as a destination for IT offshore outsourcing improved, some Indian vendors ventured out to that country, but our interviews with them showed that many of them had bad experiences due to cultural issues and differences, thereby reducing the number of success stories of Indian vendors in New Zealand. This situation reduced the attractiveness of New Zealand as a location for Indian vendors, and decreased the potential for India's IT exports to New Zealand. In turn, it reduced the chances of New Zealand as an option, completing another balancing loop (B3). 
A manager of the IT department of a large New Zealand bank noted:

"New Zealand is a conservative society. Not in favour of outsourcing. HCL, Satyam were there in New Zealand. New Zealand's perception of India's ability to do hi-tech jobs is not favourable."

\section{Loop 8: Quality of Services loop (R5)}

When New Zealand becomes less attractive as a location for Indian vendors, it was revealed in some of their interviews that they stopped deploying good staff to New Zealand. This reduced Indian vendor's quality of service to New Zealand clients and any possible success stories that might have been created. Such a situation will further reduce the location attractiveness of New Zealand, thus completing the fourth reinforcing loop.

A manager of a large IT service firm mentioned:

"Indian companies don't deploy best resources (in New Zealand). Not the best quality resources, as they are sent to USA."

The two phases used in this study, problem structuring and causal loop modelling, were useful in analysing the problem situation holistically. Specifically, the BOT graph developed during the problem structuring phase helped in capturing the complexity of the problem situation using the trends of the main variables in the system. A BOT graph essentially captured the behaviour of the system.

The causal loop model, which was useful in identifying the complex interconnections between the different variables related to the problem situation, captured the structure of the system in terms of the feedback loops operating in the system and was used to explain the complexity of the problem situation presented in the BOT graph.

\section{Conclusions}

According to systems thinking, structure dictates behaviour (Forrester, 1961). This means that the casual loop model presented in Figure 3 shows the underlying structure of this system and is responsible for the behaviour that was presented as the BOT graph in Figure 2. This also means that to change the behaviour of the system, structural changes are necessary. However, human tendency is to use some quick fixes to solve the problem for a short period of time (Maani and Cavana, 2010).

Our study was guided by the question: why is the degree of trade in IT between New Zealand and India low? The results from our research identified 25 variables and their complex interactions in the form of eight causal loops which negatively and positively influences the trade in IT between the two countries. Instead of highlighting a few factors as explanatory variables, this study provides explanation for the current state of trade which has implications for practice and theory.

The study is based on a relatively limited number of respondents predominantly from vendor side and as such the results may not be useful for generalization. In terms of practice, the study provides useful insights for information systems professionals in the IT services industry. The study highlights a few strategic initiatives to improve IT offshore outsourcing between India and New Zealand. In this respect, some of the vendors involved in this study, discussed the model and its feedback loops and came up with a few strategic initiatives for long term changes. Two of these initiatives are discussed in this section. The first initiative related to strengthening the India-US History loop $\left(R_{1}\right)$. Most of the Indian vendors suggested the idea of 'following their US clients' if they started some activities in New Zealand. Strategic initiatives by New Zealand government to encourage such US companies to start their branches and activities in New Zealand 
could bring some of their Indian vendors to New Zealand.

Another strategic initiative proposed by the vendors was about addressing the New Zealander Attitude loop $\left(\mathrm{B}_{3}\right)$ and Quality of Services loop $\left(R_{5}\right)$. In June 2011 the Prime Minister of New Zealand visited India to negotiate a free trade agreement between the two countries. The vendors suggested that this negotiation could include New Zealand government opening up some large public IT projects for open international bidding, and encourage some of the top Indian IT vendors to compete in this bidding. It was felt that this could result in a strong presence of a few quality Indian companies in New Zealand. Such a presence of top Indian IT vendors will lead to success stories, which in turn will encourage these vendors to continue deploying good staff in New Zealand projects, thereby improving their quality of service. Such success stories can also highlight different aspects of New Zealand's attractiveness, like the attractiveness of skill shortage as captured in loop $R_{2}$. As an additional initiative from the vendors, the National Association of Software and Services Companies (NASSCOM), which represents the interests of the Indian IT vendors, recently presented a submission to the Department of Immigration in Australia in collaboration with the Australian Computer Society for a market based compensation model for ICT professionals on the Visa Subclass 457. This proposal is aligned with the Australian and New Zealand Standard Classification of Occupations (ANZSCO). Since NASSCOM Australia seeks to promote trade in IT between India and Australia - New Zealand, this initiative is expected to further promote movement of Indian personnel to the region for IT services.

In terms of theory, while most of IT offshore outsourcing studies are based on client perspectives (Schoenherr, 2010) this study takes a vendor perspective. The variables presented in table 4 and the eight feedback loops presented in figure 3 together serves to build a theory to explain the low trade in
IT between New Zealand and India. Future research could build on this model to develop mathematical explanation for linkages and validation (Sterman, 2000). In addition, it has extended the literature on vendor risks (e.g. Aundhe and Mathew, 2009) by conducting a systemic analysis of these risks. It also provides a different methodological approach, based on the systems thinking and modelling methodology (Maani and Cavana, 2007) to understand complex problems related to IT offshore outsourcing.

Transaction cost economics which gives a theoretical basis to 'make or buy' decisions by firms provides another theoretical lens to analyse our findings. Our results are consistent with the principles of transaction cost economics which suggest that transaction costs in various forms determine the allocation of an economic activity between the firm and the market by a client firm. Trade between a New Zealand client and an Indian IT vendor is economically sensible when total cost, which is the sum of production cost and transaction cost, is lesser in offshore location (India) than in New Zealand. Based on our study, the casual loops "US influence', 'attitude of New Zealanders' and 'service quality' and their underlying variables provide some insights about the perception of underlying transaction costs which negatively affect outsourcing to Indian vendors by $\mathrm{New}$ Zealand firms. New Zealand clients, in the absence of success stories from a historic IT outsourcing relationship between the two countries, perceive potential opportunistic behaviour by Indian vendors. This is very unlike the US connection and history in Indian IT offshore outsourcing where trust and norms have developed over several years. Absence of historic relationship could increase ex ante costs to clients in terms of drafting, negotiating, and safeguarding an agreement (Williamson, 1985, p. 20). From the behavioural stand point ex post, deployment of quality resources by Indian vendors to New Zealand clients is a potential opportunistic behaviour perceived 
by New Zealand clients. This behaviour could arise as client have difficulty to monitor the quality of staff they get vis-à-vis US clients (due to bounded rationality). This behaviour could potentially contribute to poor 'service quality' of deliverables ex post. The ex post transaction costs emerged from this study are also consistent with prior studies in IT outsourcing using TCE which have identified coordination costs and operations risks as transaction costs to clients (Clemons, Reddy and Row, 1993).

Our study shows that transaction costs estimated by New Zealand clients arise more from behavioural aspects of bounded rationality and opportunism rather than asset specificity, uncertainty and frequency which are attributes of transactions (Williamson, 1985). Further, number of Indian vendors in New Zealand is quite less as compared to those in North America. Clients also worry about small number bargaining and subsequent opportunistic behaviour by providers (Williamson, 1985; Clemons et al., 1993). Clients also apparently perceive high transition costs due to the higher cultural and geographical distances between the two nations, and are concerned about the need for reliable connectivity also. These elements add to the transaction costs which could further lower economic efficiency of offshore outsourcing. The total cost arising from production cost and transaction costs estimated by New Zealand clients are higher in India as compared to other locations.

To summarise, this study has explained how a systemic analysis could be used for understanding the complex interaction of factors related to IT offshore outsourcing between India and New Zealand. As mentioned in the systems literature, it showed how causal loop models could be used as a means of describing and facilitating the analysis of complex systems (Maani and Cavana, 2007). Finally, this study presents a platform for building a system dynamics simulation model, capable of developing and evaluating different strategic options for improving IT offshore outsourcing between India and New Zealand.

\section{References}

Aron, R., Clemons, E. K. and Reddi, S. (2005). "Just right outsourcing: understanding and managing risk", Journal of management information systems, 22 (2), pp. 37-55.

Arora, A., Arunachalam, V.S., Asundi, J. and Fernandes, R. (2001), "The Indian software services industry," Research Policy, 30 (8), pp. 1267-1287.

Aundhe, M. D. and Mathew, S.K. (2009). "Risk mitigation in offshore IT outsourcing contracts: a service provider perspective," European Management Journal, 27 (6), pp. 418428.

Barthélemy, J. and Geyer, D. (2005). "An empirical investigation of IT outsourcing versus quasi-outsourcing in France and Germany," Information \& Management, 42 (4), pp. 533-542.

Bhattacharya, M. and Vickery, G. (2010). "The information and communication technology sector in India: performance, growth and key challenges," Working Party on the Information Economy, Directorate for science, technology and industry committee for information, computer and communications policy, OECD, 30 June, 2010.

Brocklesby, J. (1993). "Methodological complementarism or separate paradigm development - examining the options for enhanced operational research," Australian Journal of Management, 2 (18), pp. 133-157.

Carmel, E. and Agarwal, R. (2002). "The maturation of offshore sourcing of Information Technology work," MIS Quarterly Executive, 1 (2), pp. 65-78. 
Carmel, E. and Tjia, P. (2005), Offshoring Information Technology, sourcing and outsourcing to a global workforce, Cambridge University Press: Cambridge, UK.

Cavana, R.Y. and Mares, E. D. (2004). "Integrating critical thinking and systems thinking: From premises to causal loops," System Dynamics Review, 20 (3), pp. 223-235

CECA. (2009). "Comprehensive Economic Cooperation Agreement, India-New Zealand Joint Study for a Free Trade Agreement," Retrieved from http://www.mfat.govt.nz/Trade-andEconomic-Relations/2-TradeRelationships-andAgreements/India/index.php on June 10, 2011).

Checkland, P. (1981). Systems Thinking, Systems Practice. John Wiley and Sons: Chichester, UK.

CRISINFAC, (2009). State of the Industry, CRISIL IT Services Annual Review.

Clemons E. K. and Hitt L. M. (1997). "Strategic Sourcing for Services: Assessing the Balance between Outsourcing and Insourcing", Operations \& Information Management Working Paper [97-0601], Wharton School of the University of Pennsylvania.

Clemons, E., Reddi, S. and Row, S. (1993). "The impact of information technology on the organization of economic activity: The "move to the middle" hypothesis," Journal of Management Information Systems, 10 (2), pp. 9-35.

Davies, J. (2002). "Models of governance a viable systems perspective," The Australian Journal of Information Systems, 9 (2), pp. 57-66.

Davies, J., Mabin, V.J. and Balderstone, S.J. (2005). "The Theory of Constraints: a methodology apart? - a comparison with selected OR/MS methodologies," OMEGA The International Journal of
Management Science, 33 (6), pp. 506524.

Dibbern, J., Goles, T., Hirschheim, R. and Jayatilaka, B. (2004). "Information systems outsourcing: a survey and analysis of the literature", The DATA BASE for Advances in Information Systems, 35 (4), pp. 6-102.

Dou, Y. and Sarkis, J. (2010). "A joint location and outsourcing sustainability analysis for a strategic offshoring decision," International Journal of Production Research, 48 (2), pp. 567 592.

Dungey, M., Fry, R. and Martin, V. (2003). "Equity transmission mechanisms from Asia to Australia: interdependence or contagion?" Australian Journal of Management, 28 (2), pp. 157-182.

Elias, A.A. (2008). "Towards a shared mental model of stakeholders in an environmental conflict," International Transactions in Operational Research, 15, pp. 239-253

Escanlar, R. (2011). "Cost efficiency remains top factor in shifting IT work offshore," Retrieved from http://www.microsourcing.com/blog/co st-efficiency-remains-top-factor-inshifting-it-work-offshore.asp on June 10, 2011.

French, A. And Shim, J. P. (2013). "Influence of American Institutions on Information Systems (IS) research within Asia," Pacific Asia Journal of the Association of Information Systems, 4 (4), pp. 43-59

Frenkel, S. (2002). "Workplace Relations: Past, Present and Future," Australian Journal of Management, 27 (1), pp. 149-159.

Friedman, T. (2005). The world is flat, a brief history of the globalized world in the $21^{\text {st }}$ century. Penguin Books: London. 
Forrester, J.W. (1961). Industrial Dynamics. Pegasus Communications:

Waltham, MA.

Graf, M. and Mudambi, S.M. (2005). "The outsourcing of IT enabled business processes: a conceptual model of the location decision," Journal of International Management, 11 (2), pp. 253-268.

Gottfredson, M., Puryear R. and Philips S. (2005). "Strategic Sourcing from Periphery to the Core, Harvard Business Review," 83 (2), pp.132-139.

Gurbaxani, V. (1990). "Diffusion in computing networks: the case of BITNET," Communications of the ACM, 33 (12), pp. 65-75.

Heeks, R. (1998). "The uneven profile of Indian software exports," Working paper [3], Working Paper Series, Institute for Development Policy and Management, University of Manchester, Manchester, UK.

Khan.N., Currie, L.W., Weerakkody, V., and Desai, B. (2002). Evaluating offshore IT outsourcing in India: supplier and customer scenarios, $36^{\text {th }}$ Hawaii International Conference on System Science, Hawaii, USA.

Kumar, N., Stern, L.W. and Anderson, J.C. (1993). "Conducting interorganizational research using key informants," Academy of Management Journal, 36 (6), pp. 1633-1651.

Lacity, M. C. and Willcocks, L.P.(1998). "An empirical investigation of information technology sourcing practices: Lessons from experience," MIS Quarterly, 22 (3), pp. 363-408.

Lee, J.N., Huynh, M.Q., Chi-wai, K.R. and Pi, S.M. (2000). "The evolution of outsourcing research: what is the next issue?", Proceedings of the 33rd Hawaii International Conference on System Science (HICSS), Hawaii, USA.
Lee J., Huynh M. Q., Kwok R. C., and Pi S. (2003). "IT outsourcing past, present and future," Communications of the ACM, 46 (5), pp. 84-89.

Lee, J.N., Miranda, S. M. and Kim, Y.M. (2004). "IT outsourcing strategies: Universalistic, contingency, and configurational explanations of success," Information Systems Research, 15 (2), pp. 110-131.

Levina, N. and Ross, J. (2003). "From the vendor's perspective, exploring the value proposition in information technology outsourcing", MIS Quarterly, 27 (3), pp. 331-364.

Linder, J. C. (2004), "Transformational Outsourcing," MIT Sloan Management Review, 45 (2), pp. 52-58.

Loh, L. and Venkatraman, N. (1992). "Diffusion of Information Technology outsourcing: influence sources and the Kodak effect," Information Systems Research, 3 (4), pp. 334-358.

Maani, K.E. and Cavana, R.Y. (2007). Systems Thinking, System Dynamics: Managing Change and Complexity. Pearson Education: Auckland, New Zealand.

Manning, S., Massini, S., and Lewin, A.Y. (2008). " A dynamic perspective on next-generation offshoring: the global sourcing of science and engineering talent," Academy of Management Perspectives, 22 (3), pp. 35-54.

Maskell, P., Dick-Nielsen, J., Pedersen,T. and Petersen, B. (2007). "Learning Paths to Global Offshore Outsourcing - From Cost Reduction to Knowledge Seeking," Industry and Innovation, 14 (3), pp. 239-257.

McCray, G. E. and Clark Jr, T.D. (1999). "Using system dynamics to anticipate the organizational impacts of outsourcing," System Dynamics Review, 15 (4), pp. 345-373. 
MFAT, (2013). "New Zealand-India Free Trade Agreement," Retrieved from http://www.mfat.govt.nz/Trade-andEconomic-Relations/2-TradeRelationships-and-Agreements/India/ on July 30, 2013.

Mohapatra, P.K.J., Mandal, P. and Bora, M.C. (1994), Introduction to System Dynamics Modelling. University Press, Hyderabad, India.

NASSCOM, (2009). "Indian IT-BPO Industry 2009: NASSCOM Analysis," Retrieved from

http://www.nasscom.in/upload/5216/IT Industry Factsheet-Mar 2009.pdf on June 1, 2011.

Nohria, N. (2005). "Feed R\&D - or Farm it Out?" Harvard Business Review, 83 (7), pp. 17-25.

Palvia, S.C.J. (2004). "Global outsourcing of IT and IT enabled services: a framework for choosing an (outsourcee) country," Journal of Information Technology Cases and Applications, 6 (3), pp. 1-20.

Prahlad C. K. and Hamel H. (1990). "The Core Competence of the Corporation, Harvard Business Review," 68 (3), pp. 79-91.

Porter, M. (1985). Competitive Advantage: Creating and Sustaining superior Performance. Free Press, New York, NY.

Roehling, S. T., Collofello, J. S., Hermann, B. G. and Smith-Daniels, D. E. (2000). "System dynamics modeling applied to software outsourcing decision support," Software Process: Improvement and Practice, 5 (2-3), pp.169-182

Schoenherr, T. (2010). "Outsourcing decisions in global supply chains: an exploratory multi-country survey," International Journal of Production Research, 48 (2), pp. 343-378.
Senge, P. M. (1990). The fifth discipline: the art and practice of the learning organization. Currency Doubleday: New York, NY.

Sterman, J. D. (2000). Business dynamics: systems thinking and modeling for a complex world. Irwin/McGraw-Hill: New York, NY.

Statistics New Zealand (2011). "Statistics New Zealand," Retrieved from http://www.stats.govt.nz/ on June 10, 2011.

Strauss, A. and Corbin, J. (1990). Basics of qualitative research: grounded theory procedures and techniques, Sage: Newbury Park, CA.

Ulrich, W. (1987). "Critical heuristics of social systems design," European Journal of Operational Research 31 (3), pp. 276-283.

Willcocks, L.P., Lacity, M. and Cullen, S. (2007). Outsourcing: fifteen years of learning in Oxford Handbook of ICT. Oxford University Press: United Kingdom, UK.

Williamson, O.E. (1985).The economic institutions of capitalism, The Free Press, New York.

Yin, R. K. (2014). Case Study researchDesign and Methods, $5^{\text {th }}$ edition. Sage Publications: N. Delhi

Yuanyue, F., Ye, H. and Pan, S. L. (2011). "Delivering knowledge across boundaries: A case study of Bankco's offshoring projects," Pacific Asia Journal of the Association for Information Systems, 3 (3), pp. 57-79

\section{About the Authors}

Arun Elias is the Director of MBA in the School of Management at the Victoria Business School, New Zealand. He received his Ph.D. in Management from the Victoria University of Wellington, New Zealand. His research interests include 
systems thinking, stakeholder management and operations strategy. He has published in the R\&D Management journal, Energy Policy, International Journal of Logistics Management, International Transactions of Operational Research, Journal of Environmental Planning and Management, and others.

Saji Mathew is currently an Associate Professor at the Department of Management Studies, Indian Institute of Technology Madras. His PhD research and subsequent academic work focused on the role of Information Technology in Business and Management. As a Fulbright Scholar, he did his post-doctoral research on risk mitigation in offshore IT outsourcing at the Goizueta Business School of Emory University, Atlanta (USA). His present research interests cover strategies in offshore IT outsourcing, issues in IT infrastructure management services, information privacy and data mining. His articles have been published in reputed international journals. He has about 10 years of work experience in the area of industrial automation in the Indian industry covering private and public sector companies. He has provided industrial training and consulting for companies such as Exxon Mobile, Genpact, HP Globalsoft, Oracle India, Primus Retail, L\&T and Hindustan Aeronautics Limited in addition to sponsored research projects for Nissan, Hand in Hand, Infosys and DSIR. He teaches courses such as Management Information Systems, Data Warehousing and Data Mining, IT Services \& Outsourcing, Information Systems Development and Research in IT and Organizations. 